\title{
Fly ASH Aggregates on Strength and Workability Characters of Geo-Polymer Concrete
}

\author{
T.P.Meikandaan, M.Hemapriya, K.Anitha
}

\begin{abstract}
The Present study deals with preparation of $F A$ aggregates. Artificial aggregates with FA (class C) and combination of fly ash and GGBFS were preparedTwo sorts of restoring techniques were embraced for aggregates. Restoring strategies incorporate water relieving and Chemical restoring (NaoH). The tests results the fly ash water cured and chemically cured aggregates were performed well, so these two types of aggregates were adopted for preparation of GPC mixes. The GGBFS replacement content in finalized as $30 \%$ from phase $I$ results. The GPC mixes with $8 \mathrm{M}, 10 \mathrm{M}, 12 \mathrm{M}$ NaoH Solution concentrations were cast using fly ash aggregates. Workability and strength test were done on the GPC samples. It was observed that GPC mix W6 attained a maximum compressive strength of 42.89 MPa among GPC specimens with water cured aggregates. It is observed that the specimens with chemically cured aggregates. It is observed that the GPC mix with chemical cured aggregate have better workability and bonding with the matrix.
\end{abstract}

Keywords-GPC; GGBFS; NaoH; Fly ash (class C)

\section{INTRODUCTION}

Assembling of one tone of OPC, one tone of carbon dioxide into the environment, which thusly influences the remarkable component of a worldwide temperature alteration. In reducing this global warming effect and to study the appropriateness of geo-polymer concrete as an option in contrast to the OPC to acquire a basic evaluation solid this examination has been done[1]-[4].

\section{A. Objectives}

- To artificially prepare fly ash aggregate and to study its properties.

- To pick the best aggregates dependent on the properties and to utilize these fly fiery remains totals as complete swap of coarse total for the GPC blends.

- To determine compressive strength and workability variation of GPC at $0 \%$ and $10 \%$ GGBFS percentage replacements.

\section{B. Need for the study}

The setting of the GPC is the main problem. At low temperatures the GPC does not set quickly. So geopolymer concrete is mainly used for precast members where elevated temperature curing is done. GPC we are partially replacing fly ash with GGBFS to improve setting properties[5]-[6].

Revised Manuscript Received on October 22, 2019.

T.P.Meikandaan, Department of Civil Engineering, Bharath Institute of Higher Education and Research, Chennai, India. Email: ganga_meik@yahoo.co.in

M.Hemapriya, Department of Civil Engineering, Bharath Institute of Higher Education and Research, Chennai, India. Email: meihemapriya@gmail.com

K.Anitha, Department of Civil Engineering, Bharath Institute of Higher Education and Research, Chennai, India. Email: anithakrish26@yahoo.co.in

\section{METHODOLOGY}

The methodology adopted for Study is

- Performing tests on Fly ash Aggregates

- Selection of best aggregates from the test results

- Determination of material properties

- Performing trial GPC mixes

- Casting of GPC

- Testing of GPC specimens

- Discussions

- Conclusion

\section{A. Fly Ash Aggregates}

Preparation process of FA aggregates. The various properties on the aggregates are discussed.

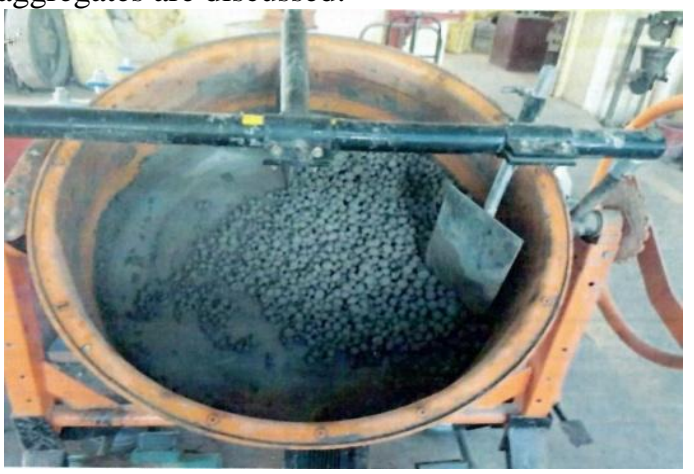

Figure - 1 Drum Pelletizer

B. Manufacturing Procedure Of Fly Ash Aggregate

First the speed and angle are adjusted according to the size of aggregate needed. Then the batched fly ash is added in to the drum and drum is allowed to rotate. The water is sprinkle at regular intervals of time until the formation of pellets start[7]-[9]. Then the drum is left to rotate for $10-15$ minutes to complete the pelletization. Fig 1 shows the drum the preparation of fly ash aggregates using drum pelletizer.

After the pelletization these aggregates are to be cured. The following curing methods are adopted.

1. Water curing: The aggregates are cured in water for 14 days.

2. Chemical curing: The aggregates are cured in $\mathrm{NaOH}$ solution for 7 days.

After the pelletization these aggregates are ready to use for their intended purposes[32]-[34].

The following are the types of aggregate combinations to be performed for the present study:

i. FA aggregate (water cured)

ii. FA aggregate (chemical cured)

iii. GGBFS replaced FA aggregate (1:5) 
iv. GGBFS replaced FA aggregate (1:3)

v. GGBFS replaced FA aggregate $(1: 2)$

\section{EXPERIMENTAL INVESTIGATION}

\section{A. Compressive Strength Test}

The individual Compressive strength of a pellet is found out by testing it under CBR testing machine as shown in fig. 4.2. The compressive strength for different aggregates are shown in the table 1.

Table - 1 Compressive Strength of FA

\begin{tabular}{|l|l|l|l|}
\hline \multirow{2}{*}{ Aggregate Type } & \multicolumn{3}{l|}{ Compressive Strength in MPa } \\
\cline { 2 - 4 } & $\mathbf{1 0 m m}$ & $\mathbf{1 2 m m}$ & $\mathbf{1 6 m m}$ \\
\hline $\begin{array}{l}\text { Pure Fly Ash } \\
\text { (Water Cured) }\end{array}$ & 4.85 & 4.55 & 4.15 \\
\hline $\begin{array}{l}\text { Fly Ash with } \\
\text { NaOH (8M) } \\
\text { Curing }\end{array}$ & 6.30 & 5.51 & 4.09 \\
\hline $\begin{array}{l}\text { Fly Ash+GGBFS } \\
\text { (5:1) }\end{array}$ & 2.95 & 2.33 & 2.15 \\
\hline $\begin{array}{l}\text { Fly Ash+GGBFS } \\
\text { (3:1) }\end{array}$ & 3.50 & 3.20 & 2.55 \\
\hline $\begin{array}{l}\text { Fly Ash+GGBFS } \\
(2: 1)\end{array}$ & 4.10 & 3.85 & 3.40 \\
\hline
\end{tabular}

B. Specific Gravity Test

The test for specific gravity is carried out on all type of aggregate and the results are tabulated below in table 2

\begin{tabular}{|c|c|}
\hline Aggregate Type & Specific Gravity \\
\hline Pure Fly Ash & 1.87 \\
\hline $\begin{array}{c}\text { Fly Ash with NaOH (8M) } \\
\text { Curing }\end{array}$ & 1.88 \\
\hline Fly Ash + GGBFS (5:1) & 1.88 \\
\hline Fly Ash + GGBFS (3:1) & 1.90 \\
\hline Fly Ash + GGBFS (2:1) & 1.91 \\
\hline
\end{tabular}

Table 2 - Specific gravity of fly ash aggregate

\begin{tabular}{|c|c|c|c|c|c|c|}
\hline \multirow{2}{*}{ Description } & \multicolumn{6}{|c|}{ Quantity (kg) } \\
\hline & $\mathrm{C}_{1}$ & $\mathrm{C}_{2}$ & $C_{2}$ & $\mathbf{C}_{4}$ & $C_{s}$ & $\mathrm{C}_{6}$ \\
\hline Fly ash & 440.36 & 440.36 & 440.36 & 308.46 & 308.46 & 308.46 \\
\hline GGBFS & - & - & - & 131.90 & 131.90 & 131.90 \\
\hline $\begin{array}{c}\text { Sodium } \\
\text { hydroxide }\end{array}$ & 44.00 & 44.00 & 44.00 & 44.00 & 44.00 & 44.00 \\
\hline $\begin{array}{l}\text { Sodium } \\
\text { silicate }\end{array}$ & 110.00 & 110.00 & 110.00 & 110.00 & 110.00 & 110.00 \\
\hline $\begin{array}{c}\text { Coarse } \\
\text { aggregate }\end{array}$ & 856.50 & 856.50 & 856.50 & 856.50 & 856.50 & 856.50 \\
\hline Quarry Dust & 568.00 & 568.00 & 568.00 & 568.00 & 568.00 & 568.00 \\
\hline $\begin{array}{c}\text { Extra water } \\
\text { (10\% wt of } \\
\text { fly } a \text { ah) }\end{array}$ & 44.04 & 44.04 & 44.04 & 44.04 & 44.04 & 44.04 \\
\hline $\begin{array}{c}\text { Super } \\
\text { plasticizer } \\
\text { (1.5\% wt of } \\
\text { fly } \mathrm{ash} \text { ) }\end{array}$ & 6.61 & 6.61 & 6.61 & 6.61 & 6.61 & 6.61 \\
\hline
\end{tabular}

Table - 6 Details for the GPC mixes with chemical cured aggregates

\section{RESULTS AND DISCUSSION}

After mixing the concrete is cast in to the moulds in 3 layers in traditional method by tamping each layer in 25 blows. Then these moulds are kept on table vibrator for 1 minute for compaction. The excess amount of concrete is scraped off by using a trowel[10]-[12]. These moulds are left for 24 hours as appeared in fig 5.3 at room temperature, After one day the blocks are de shaped and 3D squares are presented to climate till the day of the test.

\section{A. Compressive Strength}

The test is carried out to determine the compressive strength of all the GPC specimens. The slump values, dry density and compressive strength results are shown in table 1

\begin{tabular}{|c|c|c|c|c|}
\hline \multirow[t]{2}{*}{$\begin{array}{l}\text { Mix } \\
\text { No. }\end{array}$} & \multirow{2}{*}{$\begin{array}{l}\text { Mean } \\
\text { Slump } \\
(\mathrm{mm})\end{array}$} & \multirow{2}{*}{$\begin{array}{l}\text { Mean } \\
\text { Density } \\
\left(\mathrm{kg} / \mathrm{m}^{3}\right)\end{array}$} & \multicolumn{2}{|c|}{$\begin{array}{l}\text { Average Crushing } \\
\text { Strength (MPa) }\end{array}$} \\
\hline & & & 7 days & 28 days \\
\hline $\mathbf{W}_{1}$ & 80 & 2130 & 12.60 & 19.33 \\
\hline $\mathbf{W}_{2}$ & 75 & 2130 & 13.83 & 22.67 \\
\hline$W_{3}$ & 75 & 2141 & 15.67 & 26.50 \\
\hline $\mathrm{W}_{4}$ & 60 & 2135 & 29.57 & 35.13 \\
\hline $\mathrm{W}_{5}$ & 55 & 2140 & 32.10 & 38.86 \\
\hline $\mathrm{W}_{6}$ & 50 & 2153 & 33.73 & 42.13 \\
\hline
\end{tabular}

Table - 1Compressive Strength and Slump values of GPC mixes with water cured aggregates (PHASE - I)

\begin{tabular}{|c|c|c|c|c|}
\hline \multirow[t]{2}{*}{$\begin{array}{l}\text { Mix } \\
\text { No. }\end{array}$} & \multirow[t]{2}{*}{$\begin{array}{l}\text { Mean } \\
\text { Slump } \\
(\mathrm{mm})\end{array}$} & \multirow{2}{*}{$\begin{array}{l}\text { Mean } \\
\text { Density } \\
\left(\mathrm{kg} / \mathrm{m}^{3}\right)\end{array}$} & \multicolumn{2}{|c|}{$\begin{array}{l}\text { Average Crushing } \\
\text { Strength (MPa) }\end{array}$} \\
\hline & & & 7 days & 28 days \\
\hline $\mathrm{C}_{1}$ & 90 & 2190 & 24.87 & 34.30 \\
\hline $\mathrm{C}_{2}$ & 80 & 2205 & 27.33 & 36.7 \\
\hline $\mathrm{C}_{3}$ & 80 & 2210 & 30.50 & 39.40 \\
\hline $\mathrm{C}_{4}$ & 65 & 2200 & 51.73 & 55.53 \\
\hline $\mathrm{C}_{5}$ & 55 & 2204 & 53.30 & 59.43 \\
\hline $\mathrm{C}_{6}$ & 55 & 2220 & 57.37 & 64.14 \\
\hline
\end{tabular}

Table -2 Compressive Strength \& Slump values of GPC mixes with chemical cured aggregates (PHASE - I)

\begin{tabular}{|c|c|c|c|c|}
\hline \multirow{2}{*}{$\begin{array}{c}\text { Mix } \\
\text { No. }\end{array}$} & \multirow{2}{*}{$\begin{array}{c}\text { Mean } \\
\text { Slump } \\
(\mathbf{m m})\end{array}$} & \multirow{2}{*}{$\begin{array}{l}\text { Mean } \\
\text { Density } \\
\left(\mathbf{k g}^{3} \mathbf{m}^{3}\right)\end{array}$} & \multicolumn{2}{|c|}{$\begin{array}{c}\text { Average Crushing } \\
\text { Strength (MPa) }\end{array}$} \\
\cline { 4 - 5 } & & & $\mathbf{7}$ days & 28 days \\
\hline $\mathbf{W}_{1}$ & 80 & 2130 & 12.60 & 19.33 \\
\hline $\mathbf{W}_{2}$ & 75 & 2130 & 13.83 & 22.67 \\
\hline $\mathbf{W}_{3}$ & 75 & 2141 & 15.67 & 26.50 \\
\hline $\mathbf{W}_{4}$ & 60 & 2135 & 29.57 & 35.13 \\
\hline $\mathbf{W}_{5}$ & 55 & 2140 & 32.10 & 38.86 \\
\hline $\mathbf{W}_{6}$ & 50 & 2153 & 33.73 & 42.13 \\
\hline $\mathbf{C}_{1}$ & 90 & 2190 & 24.87 & 34.30 \\
\hline $\mathbf{C}_{2}$ & 80 & 2205 & 27.33 & 36.7 \\
\hline $\mathbf{C}_{3}$ & 80 & 2210 & 30.50 & 39.40 \\
\hline $\mathbf{C}_{4}$ & 65 & 2200 & 51.73 & 55.53 \\
\hline $\mathbf{C}_{5}$ & 55 & 2204 & 53.30 & 59.43 \\
\hline $\mathbf{C}_{6}$ & 55 & 2220 & 57.37 & 64.14 \\
\hline
\end{tabular}

Table 3 - Compressive Strength and Slump values of GPC mixes (Water and chemical cured) aggregates (PHASE I) 


\begin{tabular}{|c|c|c|c|c|}
\hline \multirow[t]{2}{*}{$\begin{array}{l}\text { Mix } \\
\text { No. }\end{array}$} & \multirow{2}{*}{$\begin{array}{l}\text { Mean } \\
\text { Slum } \\
\text { p } \\
(\mathrm{mm})\end{array}$} & \multirow{2}{*}{$\begin{array}{l}\text { Mean } \\
\text { Densit } \\
\mathrm{y} \\
\left(\mathrm{kg} / \mathrm{m}^{3}\right)\end{array}$} & \multicolumn{2}{|c|}{$\begin{array}{l}\text { Average Crushing } \\
\text { Strength }(\mathrm{MPa})\end{array}$} \\
\hline & & & 7 days & 28 days \\
\hline$W_{1}$ & 85 & 2124 & 16.47 & 20.59 \\
\hline $\mathrm{W}_{2}$ & 70 & 2121 & 16.11 & 20.44 \\
\hline$W_{3}$ & 80 & 2133 & 15.93 & 23.41 \\
\hline $\mathrm{W}_{4}$ & 65 & 2142 & 34.44 & 36.15 \\
\hline $\mathrm{W}_{5}$ & 60 & 2145 & 34.42 & 37.93 \\
\hline $\mathrm{W}_{6}$ & 60 & 2151 & 34.46 & 42.89 \\
\hline
\end{tabular}

Table 4 - Compressive Strength and Slump values of GPC mixes with water cured aggregates (PHASE - II)

\begin{tabular}{|c|c|c|c|c|}
\hline \multirow[t]{2}{*}{$\begin{array}{l}\text { Mix } \\
\text { No. }\end{array}$} & \multirow{2}{*}{$\begin{array}{l}\text { Mean } \\
\text { Slump } \\
(\mathrm{mm})\end{array}$} & \multirow{2}{*}{$\begin{array}{l}\text { Mean } \\
\text { Density } \\
\left(\mathrm{kg} / \mathrm{m}^{3}\right)\end{array}$} & \multicolumn{2}{|c|}{$\begin{array}{l}\text { Average } \quad \text { Crushing } \\
\text { Strength }(\mathrm{MPa})\end{array}$} \\
\hline & & & 7 days & 28 days \\
\hline $\mathrm{C}_{1}$ & 95 & 2178 & 29.48 & 35.26 \\
\hline $\mathrm{C}_{2}$ & 85 & 2207 & 29.05 & 37.48 \\
\hline $\mathrm{C}_{3}$ & 90 & 2296 & 29.53 & 39.88 \\
\hline $\mathrm{C}_{4}$ & 60 & 2213 & 57.11 & 56.28 \\
\hline $\mathrm{C}_{5}$ & 65 & 2207 & 56.13 & 60.10 \\
\hline $\mathrm{C}_{6}$ & 55 & 2234 & 56.00 & 64.56 \\
\hline
\end{tabular}

Table 5 - Compressive Strength and Slump values of GPC mixes with chemical cured aggregates (PHASE - II)

\begin{tabular}{|c|c|c|c|c|}
\hline \multirow[t]{2}{*}{$\begin{array}{l}\text { Mix } \\
\text { No. }\end{array}$} & \multirow{2}{*}{$\begin{array}{l}\text { Mean } \\
\text { Slump } \\
(\mathrm{mm})\end{array}$} & \multirow{2}{*}{$\begin{array}{l}\text { Mean } \\
\text { Density } \\
\left(\mathrm{kg} / \mathrm{m}^{3}\right)\end{array}$} & \multicolumn{2}{|c|}{$\begin{array}{l}\text { Average Crushing } \\
\text { Strength (MPa) }\end{array}$} \\
\hline & & & 7 days & 28 days \\
\hline $\mathrm{W}_{1}$ & 80 & 2124 & 16.47 & 20.59 \\
\hline $\mathrm{W}_{2}$ & 70 & 2121 & 16.11 & 20.44 \\
\hline $\mathrm{W}_{3}$ & 80 & 2141 & 15.93 & 23.41 \\
\hline $\mathrm{W}_{4}$ & 65 & 2133 & 34.44 & 36.15 \\
\hline$W_{5}$ & 60 & 2142 & 34.42 & 37.93 \\
\hline $\mathrm{W}_{6}$ & 60 & 2145 & 34.46 & 42.89 \\
\hline $\mathrm{C}_{1}$ & 95 & 2178 & 29.48 & 35.26 \\
\hline $\mathrm{C}_{2}$ & 85 & 2207 & 29.05 & 37.48 \\
\hline $\mathrm{C}_{3}$ & 90 & 2296 & 29.53 & 39.88 \\
\hline $\mathrm{C}_{4}$ & 60 & 2213 & 57.11 & 56.28 \\
\hline $\mathrm{C}_{5}$ & 65 & 2207 & 56.13 & 60.10 \\
\hline $\mathrm{C}_{6}$ & 55 & 2234 & 56.00 & 64.56 \\
\hline
\end{tabular}

Table 6 - Compressive Strength and Slump values of GPC mixes with (Water and chemical cured) aggregates (PHASE - II)

\begin{tabular}{|l|l|l|l|l|}
\hline \multirow{2}{*}{$\begin{array}{l}\text { Mix } \\
\text { No. }\end{array}$} & $\begin{array}{l}\text { Average } \\
\text { Strength } \\
\text { Phase-I }\end{array}$ & \multicolumn{2}{|c|}{$\begin{array}{c}\text { Crushing } \\
\text { (MPa) }\end{array}$} & \multicolumn{2}{|l|}{$\begin{array}{l}\text { Average Crushing } \\
\text { Strength } \\
\text { Phase- II }\end{array}$} \\
\cline { 2 - 5 } & $\mathbf{7}$ days & $\begin{array}{l}\mathbf{2 8} \\
\text { days }\end{array}$ & 7 days & 28 days \\
\hline $\mathbf{W}_{1}$ & 12.60 & 19.33 & 16.47 & 20.59 \\
\hline $\mathbf{W}_{2}$ & 13.83 & 22.67 & 16.11 & 20.44 \\
\hline $\mathbf{W}_{3}$ & 15.67 & 26.50 & 15.93 & 23.41 \\
\hline $\mathbf{W}_{4}$ & 29.57 & 35.13 & 34.44 & 36.15 \\
\hline $\mathbf{W}_{5}$ & 32.10 & 38.86 & 34.42 & 37.93 \\
\hline $\mathbf{W}_{6}$ & 33.73 & 42.13 & 34.46 & 42.89 \\
\hline $\mathbf{C}_{1}$ & 24.87 & 34.30 & 29.48 & 35.26 \\
\hline $\mathbf{C}_{2}$ & 27.33 & 36.7 & 29.05 & 37.48 \\
\hline $\mathbf{C}_{3}$ & 30.50 & 39.40 & 29.53 & 39.88 \\
\hline $\mathbf{C}_{4}$ & 51.73 & 55.53 & 57.11 & 56.28 \\
\hline $\mathbf{C}_{5}$ & 53.30 & 59.43 & 56.13 & 60.10 \\
\hline $\mathbf{C}_{6}$ & 57.37 & 64.14 & 56.00 & 64.56 \\
\hline
\end{tabular}

Table 7 - Work done in (Phase I \& Phase - II)

Comparison of Average Crushing Strengthin Water cured and Chemical cured Fly ash aggregates

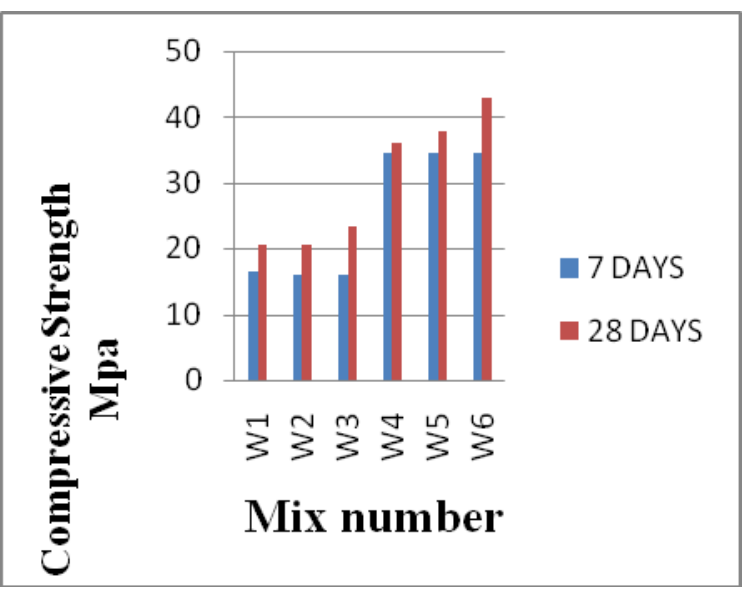

Figure - 1 Results of Compressive Strength of GPC mixes (Phase - I)

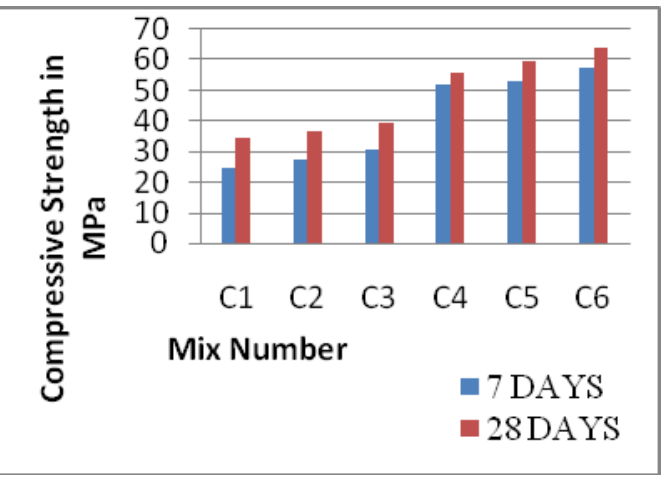

Figure - 2 Results of Compressive Strength of GPC mixes (Phase - I) 


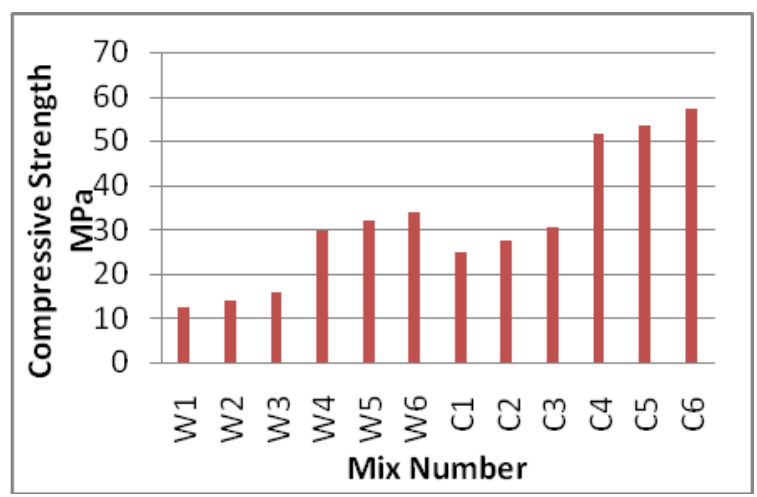

Figure - 3 Results of 7 days Compressive Strength of GPC (mixes water and chemical cured) aggregates (Phase - I)

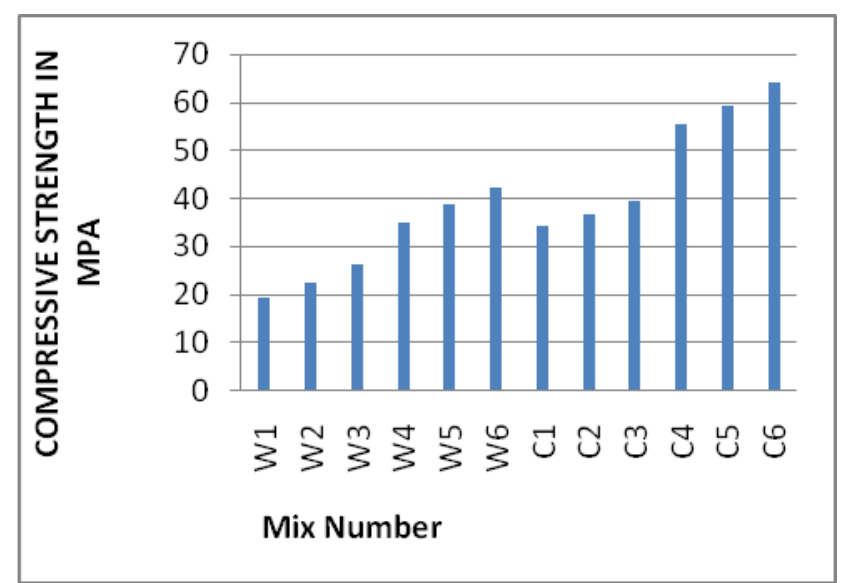

Figure - 4 Results of 28 days Compressive Strength of GPC mixes (water and chemical cured) aggregates (Phase - I)

From the fig1, 2, 3, 4 it is shown that with the increase of GGBFS replacement from $0 \%$ to $30 \%$ the compressive strength of all the GPC mixes increases nearly by $40 \%$. This demonstrates the incomplete supplanting of fly powder with GGBFS gives better setting properties and quality addition of GPC blends[13]-[17]. Maximum compressive strength of $64.14 \mathrm{MPa}$ is obtained form GPC mix $\mathrm{C}_{6}$. The compressive strength of GPC mixes increased by $45 \%$ to $50 \%$ for GPC mixes with chemical cured aggregates compared to GPC mixes with water cured aggregates.

The maximum compressive strength for GPC mix with water cured aggregates is obtained as $42.89 \mathrm{MPa}$ and for GPC mixes with chemical cured aggregates is obtained as 64.56 MPa. From the above results we can infer that these GPC mixes can be used for structural elements.

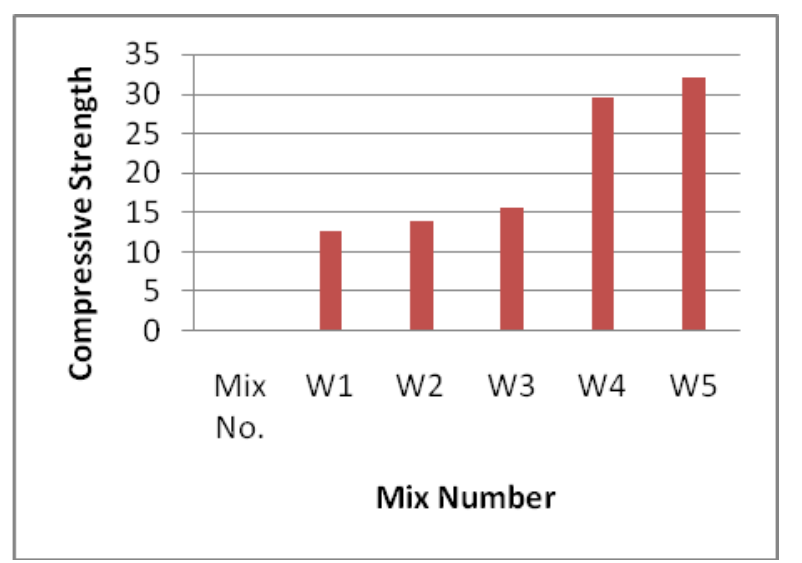

Figure - 5 Results of slump for GPC mixes with water cured aggregates (Phase - I)

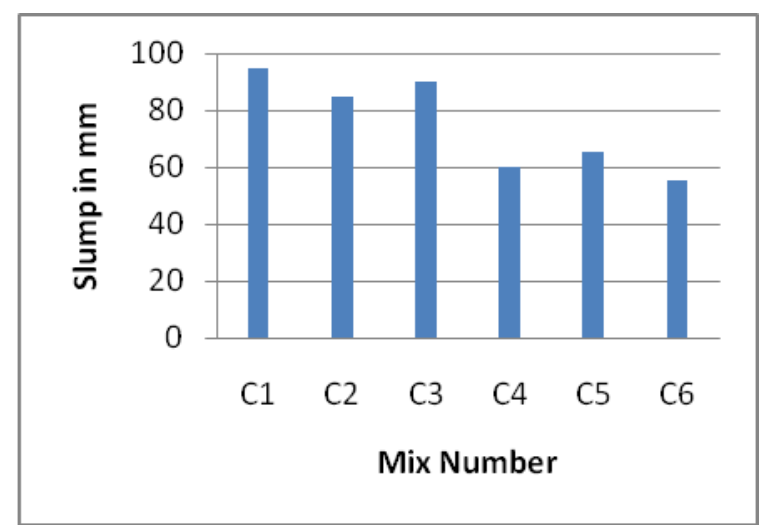

Figure - 6 Results of slump for GPC mixes with chemical cured aggregates (Phase $-\mathrm{I})$

It is seen from Fig. 6.5 and Fig. 6.6 that the slump esteems for the GPC blends with water relieved and synthetic restored totals are almost comparative[18]-[22]. Greatest droop of $90 \mathrm{~mm}$ is acquired for GPC blend $\mathrm{C} 1$. With the increase of GGBFS content from $0 \%$ to $30 \%$ there is reduction of slump value up to $25 \%$ and the slump is minimum of $50 \mathrm{~mm}$ is obtained for the GPC mix $\mathrm{W}_{6}$.

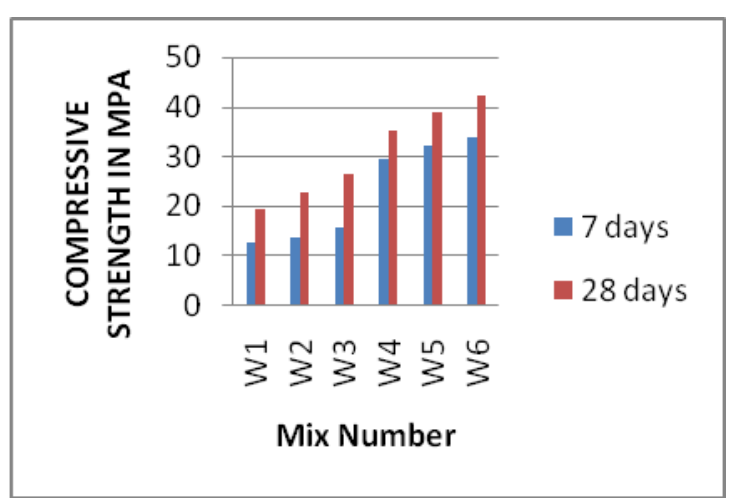

Figure - 7 Results of Compressive Strength of GPC mixes with Chemical cured aggregates (Phase - I) 


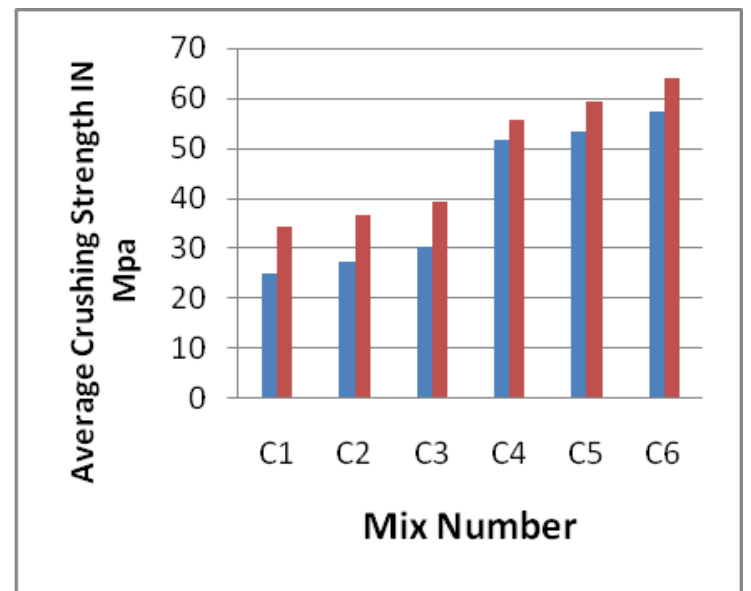

Figure - 8 Results of Average Crushing Strength of GPC mixes (Phase - II)

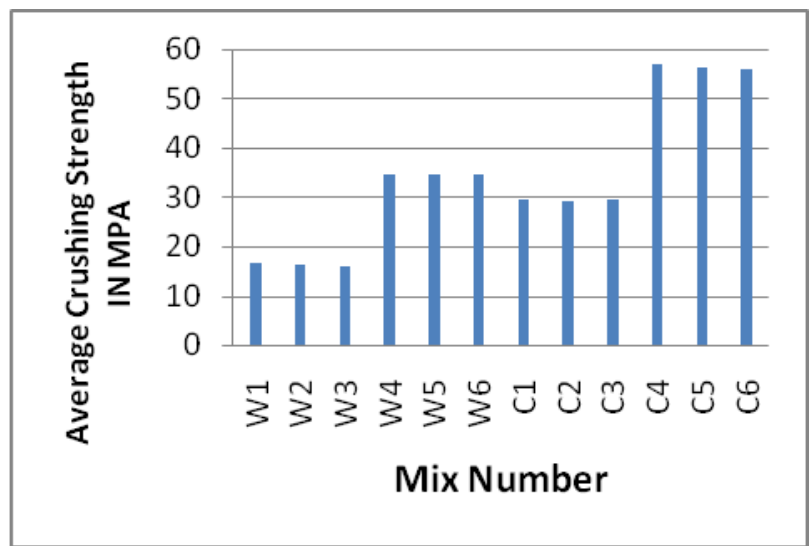

Figure - 9 Results of 7 days Average Crushing Strength of GPC mixes (water and Chemical cured) aggregates

(Phase - II)

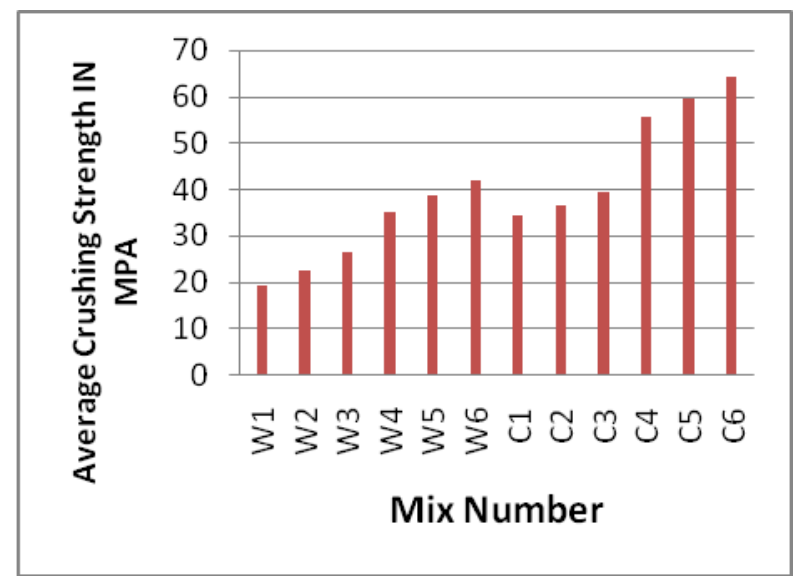

Figure - 10 Results of 28 days Average Crushing Strength of GPC mixes (Phase - II)

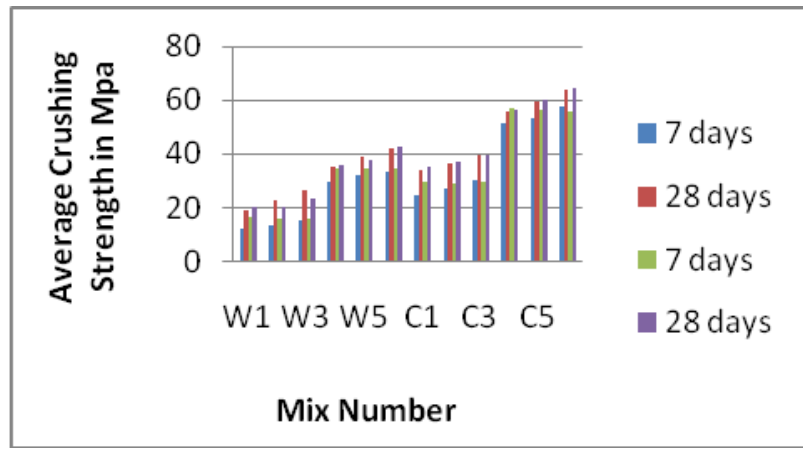

Figure - 11 Work done in (Phase I \& Phase - II) Comparison of Average Crushing Strength in (Water and Chemical cured) Fly ash aggregates

\section{V.CONCLUSION}

- The fly ash with water relieving and compound restoring acquired higher compressive quality qualities. The most extreme compressive quality of pellets acquired is 6.30 $\mathrm{MPa}$ for substance fix totals and 4.85 $\mathrm{MPa}$ for water restored totals.

- The Fly ash with compound relieving have less water ingestion because of the development of shell on the outskirts of the totals. The least water absorption is obtained as $14.20 \%$. So in order to accommodate the loss of water due to water absorption[23]-[26].

- The specific gravity of water cured fly ash aggregates is obtained as 1.87 and 1.88 for chemical cured aggregates, which is around $65 \%$ of ordinary coarse.

- As the \% GGBFS replacement increases the compressive strength of GPC also increases by $40 \%$. GPC mixes with partial replacement of Fly ash with GGBFS the compressive strength increases. So, the maximum compressive strength achieved is 64.56. MPa for GPC mix $\mathrm{C}_{6}$ with chemical cured aggregates.

- The compressive strength for GPC mix increased nearly by $40 \%$ for $0 \%$ to $30 \%$ GGBFS replacement irrespective of type of aggregate.

- GGBFS makes the setting and solidifying properties of GPC better. The functionality of GPC blend lessens with increment in \% GGBFS substitution. The slump is of 90 $\mathrm{mm}$ is acquired for GPC blend $\mathrm{C} 1$ with $0 \%$ GGBFS substitution and synthetic restored fly slag totals.

- It is observed from the tested GPC specimens that the bonding of aggregates with the matrix is better for the GPC specimens with chemical cured fly ash aggregates.

- The usage of GGBFS in GPC can overcome the curing problems of GPC to adopt it for normal construction work and from the test results obtained and it is stated that these GPC mixes $\mathrm{C}_{4}, \mathrm{C}_{5}$ and $\mathrm{C}_{6}$ can be used for structural purposes[27]-[31].

- Finally using GPC with fly ash aggregates as an alternative of ordinary cement concrete will reduce the $\mathrm{CO}_{2}$ emission in to the atmosphere and make environment eco-friendly. 


\section{REFERENCES}

1. Iyappan L., Dayakar P., Identification of landslide prone zone for coonoortalukusing spatial technology, International Journal of Applied Engineering Research,V-9,I-22,PP-5724-5732,Y-2014.

2. Kumar J., Sathish Kumar K., Dayakar P.,Effect of microsilica on high strength concrete, International Journal of Applied Engineering Research,V-9,I-22,PP-5427-5432,Y-2014.

3. Dayakar P., Vijay Ruthrapathi G., Prakesh J., Management of bio-medical waste, International Journal of Applied Engineering Research,V-9,I-22,PP-5518-5526,Y-2014.

4. Swaminathan N., Dayakar P., Resource optimization in construction project, International Journal of Applied Engineering Research,V-9,I-22,PP-5546-5551,Y-2014.

5. Venkat Raman K., Dayakar P., Raju K.V.B.,An experimental study on effect of cone diameters in penetration test on sandy soil, International Journal of Civil Engineering and Technology,V-8,I-8,PP-1581-1588,Y-2017.

6. Saritha B., Chockalingam M.P.,Photodradation of malachite green DYE using TIO2/activated carbon composite,International Journal of Civil Engineering and Technology,V-8,I-8,PP-156-163,Y-2017

7. Shendge R.B., Chockalingam M.P., Saritha B., Ambica A.,Swat modelling for sediment yield: A case study of Ujjani reservoir in Maharashtra, India,International Journal of Civil Engineering and Technology,V-9,I-1,PP-245-252,Y-2018

8. Chockalingam M.P., Balamurgan V.,Modernisation of an existing urban road-sector in Chennai, a case study report,International Journal of Civil Engineering and Technology,V-8,I-8,PP-1457-1467,Y-2017

9. Saritha B., Chockalingam M.P.,Adsorption study on removal of basic dye by modified coconut shell adsorbent, International Journal of Civil Engineering and Technology,V-8,I-8,PP-1370-1374,Y-2017

10. Saritha B., Chockalingam M.P.,Adsorptive removal of heavy metal chromium from aqueous medium using modified natural adsorbent,International Journal of Civil Engineering and Technology,V-8,I-8,PP-1382-1387,Y-2017

11. Chockalingam M.P., Palanivelraja S.,Retrospective analysis of a theoretical model used for forecasting future air quality near the north Chennai thermal power plant,International Journal of Civil Engineering and Technology,V-8,I-8,PP-1457-1467,Y-2017

12. Saritha B., Chockalingam M.P.,Photodegradation of methylene blue dye in aqueous medium by $\mathrm{Fe}-\mathrm{AC} / \mathrm{TiO} 2$ Composite,Nature Environment and

Pollution Technology,V-17,I-4,PP-1259-1265,Y-2018

13. Shendge R.B., Chockalingam M.P., Kaviya B., Ambica A.,Estimates of potential evapotranspiration rates by three methods in upper Bhima Basin, In Maharashtra, India,International Journal of Civil Engineering and Technology,V-9,I-2,PP-475-480,Y-2018

14. Shendge R.B., Chockalingam M.P.,The soil and water assessment tool for Ujjani Reservoir,International Journal of Mechanical Engineering and Technology,V-9,I-2,PP-354-359,Y-2018

15. Shendge R.B., Chockalingam M.P.,A review on soil and water assessment tool,International Journal of Mechanical Engineering and Technology,V-9,I-2,PP-347-353,Y-2018

16. Sachithanandam P., Meikandaan T.P., Srividya T.,Steel framed multi storey residential building analysis and design,International Journal of Applied Engineering Research,V-9,I-22,PP-5527-5529,Y-2014

17. Meikandaan T.P., Ramachandra Murthy A.,Study of damaged RC beams repaired by bonding of CFRP laminates,International Journal of Civil Engineering and Technology,V-8,I-2,PP-470-486,Y-2017

18. Meikandaan T.P., Ramachandra Murthy A.,Retrofittng of reinforced concrete beams using GFRP overlays,International Journal of Civil Engineering and Technology,V-8,I-2,PP-423-439,Y-2017

19. Meikandaan T.P., Ramachandra Murthy A.,Flexural behaviour of RC beam wrapped with GFRP sheets, International Journal of Civil Engineering and Technology,V-8,I-2,PP-452-469,Y-2017

20. Meikandaan T.P., Murthy A.R.,Experimental study on strengthening of rc beams using glass Fiber,International Journal of Civil Engineering and Technology,V-9,I-11,PP-959-965,Y-2018

21. Meikandaan T.P., Hemapriya M.,Use of glass FRP sheets as external flexural reinforcement in RCC Beam,International Journal of Civil Engineering and Technology,V-8,I-8,PP-1485-1501,Y-2017

22. Saraswathy R., Saritha B.,Planning of integrated satellite township at Thirumazhisai,International Journal of Applied Engineering Research,V-9,I-22,PP-5558-5560,Y-2014

23. Saritha B., Ilayaraja K., Eqyaabal Z.,Geo textiles and geo synthetics for soil reinforcement,International Journal of Applied Engineering Research,V-9,I-22,PP-5533-5536,Y-2014
24. Ambica A., Saritha B., Changring G., Singh N B., Rajen M., Salman Md.,Analysis of groundwater quality in and around Tambaram taluk, Kancheepuram district,International Journal of Civil Engineering and Technology,V-8,I-8,PP-1362-1369,Y-2017

25. Arunya A., Sarayu K., Ramachandra Murthy A., Iyer N.R.,Enhancement of durability properties of bioconcrete incorporated with nano silica,International Journal of Civil Engineering and Technology,V-8,I-8,PP-1388-1394,Y-2017

26. Ilayaraja K., Krishnamurthy R.R., Jayaprakash M., Velmurugan P.M., Muthuraj S.,Characterization of the 26 December 2004 tsunami deposits in Andaman Islands (Bay of Bengal, India),Environmental Earth Sciences, V-66,I-8,PP-2459-2476,Y-2012

27. Ilayaraja K.,Morphometric parameters of micro watershed in Paravanar sub-basin, Cuddalore District,International Journal of Civil Engineering and Technology,V-8,I-8,PP-1444-1449,Y-2017

28. Ilayaraja K., Singh R.K., Rana N., Chauhan R., Sutradhar N.,Site suitability assessment for residential areas in south Chennai region using remote sensing and GIS techniques,International Journal of Civil Engineering and Technology,V-8,I-8,PP-1468-1475,Y-2017

29. Ilayaraja K., Reza W., Kumar V., Paul S., Chowdhary R.,Estimation of land surface temperature of Chennai metropolitan area using Landsat images,International Journal of Civil Engineering and Technology, V-8,I-8,PP-1450-1456,Y-2017

30. Chitra R.,Experimental study on beam using steel fiber and latex,International Journal of Civil Engineering and Technology,V-8,I-8,PP-1395-1403,Y-2017

31. Chitra R.,Analysis of traffic and management at Kovilambakkam intersection,International Journal of Civil Engineering and Technology,V-8,I-8,PP-1433-1443,Y-2017

32. Aswathy M.,Experimental study on light weight foamed concrete,International Journal of Civil Engineering and Technology,V-8,I-8,PP-1404-1412,Y-2017

33. Aswathy M.,Wastewater treatment using constructed wetland with water lettuce (Eichornia Crasipies),International Journal of Civil Engineering and Technology,V-8,I-8,PP-1413-1421,Y-2017

34. Kiruthiga K., Anandh K.S., Gunasekaran K, Assessment of influencing factors on improving effectiveness and productivity of construction engineers, 2015, International Journal of Applied Engineering Research, V - 10,I -17,p -13849-13854.

\section{AUTHORS PROFILE}

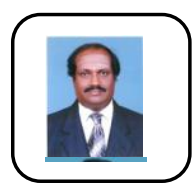

T.P.Meikandaan Associate Professor, Department of Civil Engineering, Bharath Institute of Higher Education and Research, Chennai , India.

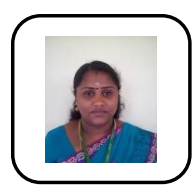

M.Hemapriya Assistant Professor, Department of Civil Engineering, Bharath Institute of Higher Education and Research, Chennai, India.

K.Anitha Assistant Professor, Department of Civi Engineering, Bharath Institute of Higher Education and Research, Chennai, India. 